idea that the friction of fragments of the silage upon the ruminal epithelium may also constitute a mechanical stimulus.

To verify this hypothesis, we used calves receiving milk exclusively through abomasal fistula in order to compare the action of intraruminal infusions composed of volatile fatty acids and a solution of ammonia with that of plastic particles introduced through a rumen fistula :

- the plastic particles develop the muscle layer of the rumen wall without inducing development of the papilla, a fact which is probably due to the mechanical stimulation of the reflexogenous zones of the motricity (Ruckebusch and Candau, C. R. Soc. Biol., 62, 897; Candau, C. R. Acad. Sci., 1970, in press).

- the volatile fatty acids induce an important development of the mucous membrane and a perfect development of the papilla. The combination of plastic and volatile fatty acids has a synergic action upon the mucous membrane as well as upon the muscle layer.

- ammonia constitutes, as the VFA, a chemical stimulus of the development of the mucous membrane and of its papilla, these two stimuli being efficient by decreasing order : V.F.A. $\mathrm{NH}_{3}$.

These results show that the active metabolism within the rumen epithelium is one of the most determining factors of the anatomical development of the rumen.

\title{
APPLICATION DE DIVERS ASPECTS DE LA TEChNiQUE DE RÉGRESSION A L'ÉTUdE DU TRANSIT DIGESTIF
}

\author{
R. TOMASSONE et J.-P. LAPLACE \\ Laboratoive de Biométrie, \\ Station de Recherches sur l'Élevage des Porcs, \\ Centre national de Recherches zootechniques, I. N.R. A., \\ 78 - Jouy-en-Josas
}

La recherche d'une méthode de traitement des courbes d'évacuation gastro-duodénale, permettant des comparaisons expérimentales rigoureuses sur la base de paramètres quantitatifs précis, doit se plier à deux impératifs :

I. la forme analytique, qui fournit les paramètres quantitatifs, doit être la même dans tous les cas,

2. cette forme analytique doit aussi être utilisable, c'est-à-dire ne comporter que des paramètres susceptibles de recevoir une interprétation physiologique.

On a donc étudié la régression en fonction du temps $(x)$ du volume recueilli à la sortie de l'estomac $(y)$ chez le Porc après un repas constitué d'un aliment naturel à base d'orge.

La régression progressive multiple (I) fournit de très nombreuses formes analytiques dont la validité reste limitée à telle ou telle situation expérimentale (traitement). La régression polynomiale au sens strict fournit dans tous les cas une équation d'une courbe représentative simulant la fonction du temps la mieux ajustée aux valeurs observées et donnant la description la plus proche de la réalité. Cette équation est d'une complexité variable (deuxième au cinquième degré). Mais l'analyse montre que dans 63 p. roo des cas il s'agit d'un polynôme du troisième degré, et 
que dans les 37 p. roo des cas restants, les polynômes peuvent être ramenés arbitrairement au troisième degré sans nuire sensiblement à l'ajustement.

La forme analytique utilisable choisie en définitive est donc le polynôme du troisième degré

$$
y=b_{0}+b_{1} x+b_{2} x^{2}+b_{3} x^{3}
$$

L'analyse de variance (2) réalisée sur les coefficients polynomiaux $\left(b_{0}, b_{1}, b_{2}, b_{3}\right)$ permet de proposer une interprétation physiologique simple de ces coefficients, dans la perspective d'une régulation purement mécanique par intéroception des volumes digestifs en présence de part et d'autre du pylore. Les coefficients polynomiaux sont en l'occurrence les paramètres quantitatifs utilisables comme révélateurs pour toutes les comparaisons expérimentales.

\section{SUMMARY}

\section{APPLICATION OF SOME ASPECTS OF THE REGRESSION TECHNIQUE TO THE STUDY} OF THE DIGESTIVE TRANSIT

A method for the analysis of the gastro-duodenal emptying curves by means of which one may obtain strict experimental comparisons on the basis of precise quantitative parameters must depend on two main factors :

r. The analytical form, providing the quantitative parameters, must be the same for all the cases.

2. The analytical form must make sense, i. e., all the parameters must have a biological interpretation.

The regression of the volume collected at the outlet of the stomach $(y)$ on the time $(t)$ was studied in the pig after a natural meal containing mainly barley.

The stepwise multiple regression ( $\mathrm{I}$ ) gives several analytical forms, whose validity is limited to the experimental treatment. The polynomial fitting always gives the equation of a curve very close to the values observed. The degree varies from 2 to 5 ; in $63 \mathrm{p}$. Ioo of the cases, it is a third degree polynomial and in the remaining cases, the polynomials can be adjusted arbitrarily to the third degree without altering the results.

The analytical form chosen is therefore the third degree polynomial

$$
y=b_{0}+b_{1} x+b_{2} x^{2}+b_{3} x^{3}
$$

The analysis of variance (2) carried out with these polynomial coefficients gives a simple physiological interpretation of the coefficients, with a view to a purely mechanical control by interoception of the digestive volumes on both sides of the pylorus. The polynomial coefficients are the quantitative parameters used for the exprimental comparisons.

\section{RÉFÉRENCES BIBLIOGRAPHIQUES}

(I) DRAPER N. R., Smith H., I966. Applied regression analysis. John Wiley, New York, 407 p.

(2) ReEs D. H., I966. The analysis of variance of designs with many non orthogonal factors. J.R. Statist. Soc. B, 28, I10-II7. 